\title{
Perspectives and Challenges from the 20th Century
}

\author{
F. H. Tainter
}

Department of Forest Resources, Clemson University, Clemson, SC 29634.

Accepted for publication 7 March 2003.

\begin{abstract}
Tainter, F. H. 2003. Perspectives and challenges from the 20th century. Phytopathology 93:1056-1061.

The magnitude of change in our understanding of tree diseases during the past century is almost incomprehensible. This does not mean to imply that we know everything, but the science of forest pathology has come a long way in the past 100 years. This remarkable progress was driven by three events: (i) an investment in the early 1900s in federal and state experiment stations, which established the need for, and benefits of, research in tree diseases; (ii) veterans acquiring an education under the GI Bill, which created a pool of forest pathologists and students eager to
\end{abstract}

ABSTRACT solve the devastation caused by diseases such as chestnut blight, white pine blister rust, Dutch elm disease, and oak wilt; and (iii) the McIntireStennis Cooperative Forestry Program, which established a strategy for the federal government to assist the financing of forestry research in the universities. Although all three of these events are being drastically modified by a discontented tax-paying public, the threats of changing land use patterns, population pressures, and exotic pests on fragile forested ecosystems will certainly force a renaissance in our field that will dwarf progress of the past century and help assure an acceptable quality of life in the new century. The magnitude of what forest pathologists will accomplish, to a great extent, depends on what the public is willing to pay for.
In the following paragraphs, I will attempt to summarize where we have been, where we are now, and where, I think, we are going. This presentation will consist of three parts. I will devote a few paragraphs to reviewing the past. I will then present a few thoughts about the present situation within our profession; and then close with some hopefully prophetic words of wisdom about what the future holds for our beloved profession. Most of my comments will focus on the science of forest pathology in North America, and more specifically in the United States.

The past. Forest pathology developed as a subset of the more general field of plant pathology. The fledgling profession of plant pathology began to come into its own by the mid-1800s, owing its birth in no small part to the public concern created by the devastating Irish potato blight and resulting famine. The first forest pathologist, Robert Hartig, in 1874, wrote his classic treatise on forest tree diseases (5). The principles that it introduced catalyzed much of what forest pathologists have done in the succeeding 100 years. His treatise could not have come at a more opportune time. By 1900, exploitive logging had removed most of the prime white pine timber in the northern states, the emerging conservation movement coincidentally called for a moratorium of harvesting on some public lands, and a beleaguered wood products industry was beginning to explore the use of chemical wood preservatives as a means of prolonging the useful service life of wood products. The fledgling field of forest pathology was soon to receive a big boost in public support as the economic losses caused by chestnut blight were reported by the media. Ironically, another introduced pathogen, Phytophthora cinnamomi, was also killing large numbers of chestnuts but it was largely overshadowed by chestnut blight (4). A century later, history will repeat itself with a new species of Phytophthora!

Corresponding author: F. H. Tainter; E-mail address: ftainter@earthlink.net

Publication no. P-2003-0602-07O

(C) 2003 The American Phytopathological Society
The American Phytopathological Society was founded in 1908 to provide a medium in which the burgeoning number of plant pathologists could exchange ideas. Articles in that society's scientific journal Phytopathology, which started in 1911, contain the essence of the science of plant pathology, and to a large extent, they track the development of forest pathology, representing the results of countless hours of experimentation in the laboratory and in the field. I examined the tables of contents of each issue and produced a list of those articles directly relating to forest pathology. I did not include subject matter that helped to establish things such as basic principles, for example, unless that particular work was conducted with a tree pathogen. I also did not include some tree pathogens such as cedar-apple rust or pathogens affecting fruit or nut tree crops such as Macadamia nut trees. Country of origin was not differentiated. Considering this somewhat prejudiced and certainly conservative accounting, a total of at least 946 forest pathology articles are contained within the hallowed tomes of Phytopathology. Annual productivity is shown in Figure 1.

Phytopathology perhaps focuses on research of a more basic nature, whereas the journal Plant Disease (and its predecessors Plant Disease Bulletin and Plant Disease Reporter) tends to publish articles relating to more practical, or field related, problems. To date, no fewer than 1,893 articles have been published in this journal series. Figure 1 illustrates the annual forest pathology publication productivity.

The width and breadth of articles relating to forest pathology in these two journals is outstanding! No other country has come close to producing a similar record, a record which has served as a model of what can be done if adequate resources are available.

During this same time period there have been a significant number of forest pathology publications from other sources. The U.S. Department of Agriculture (USDA) Forest Service has produced an incredible number of high quality research publications, including general technical reports, research papers, and agriculture handbooks. They pioneered the use of color in a variety of pamphlets such as the insect and disease leaflets, how-to leaflets, and many others, plus slide sets, tapes, and more recently CDs. 
These are very timely publications that appear soon after a disease outbreak and are helpful to not only other scientists, but to homeowners, the lay public, and especially teachers. There is also a variety of high quality state publications that tend to focus on diseases and other pests of a local or regional nature. All of the federal and state outreach publications are composed in an informative, colorful, and easy-to-understand format for use by an interested public.

While most of what I have written here is in regard to forest pathology in the United States, we must not overlook the productivity of our Canadian colleagues. Within the Canadian Journal of Botany are 859 scientific articles relating to forest pathology (Fig. 1). Most such articles were by authors in Canadian and U.S. agencies. Federal and provincial agencies in Canada have also produced a number of outstanding forest pathology publications.

A variety of textbooks or related books that focus on tree care have been published and these summarize the changes that have occurred in our profession during this century (Table 1). While not a textbook, per se, the color reference book coauthored by Sinclair et al. (13) is the premier, state-of-the-art record of the visual side of forest pathology. As forest pathologists, we should be proud of this effort. It represents a beautiful summary of our science for the century and is a significant measure of scholarship within our profession. It is a wonderful record of our collective achievements! We eagerly anticipate the second edition!

We have seen some amazing changes in the science of forest pathology during the past 100 years. Some of the most significant achievements have been described by the other authors in these proceedings. Now, reflect about some of the things that have happened in even the past 10 to 20 years. One of the principles that I try to teach my students is that almost any human input into a forested ecosystem affords some advantage to the pathogens, and that almost every serious tree disease is serious as a result of some human input. Probably the only significant disease that has decreased as a result of intensive management is heart decay, and that has decreased mainly as a result of shorter rotations. In some forested ecosystems, we must actually manage to promote heart decay in order to provide habitat for some endangered species, such as the red-cockaded woodpecker and other cavity-nesting critters.

Our successes in forest pathology have been greatly enhanced by three or four major events. The first of these was the establishment of state and federal experiment stations early in the century. These provided physical facilities where state or federal personnel could perform experiments and demonstrations. Initially the scien-

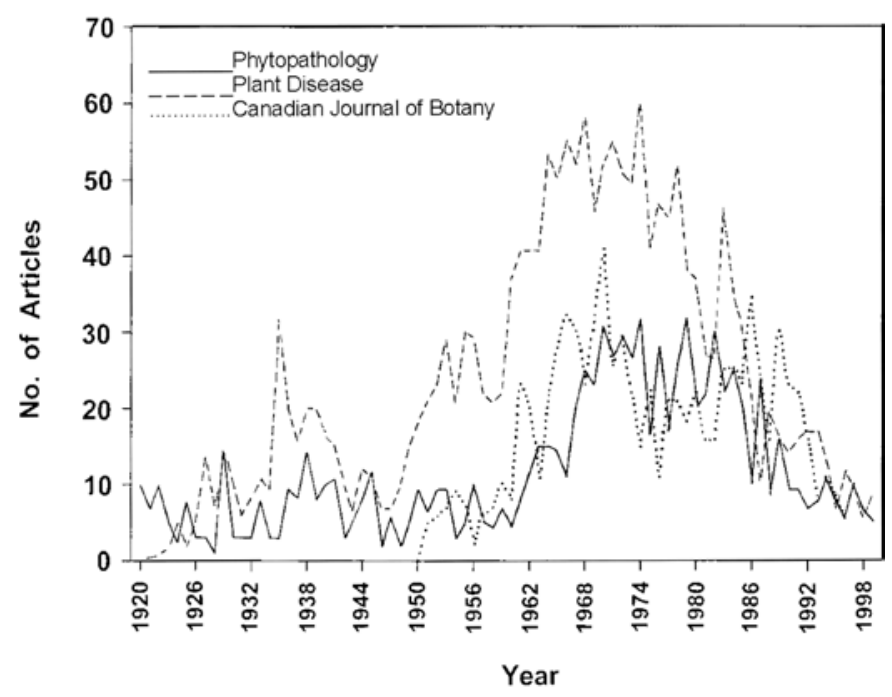

Fig. 1. Total articles relating to forest pathology published in major plant pathology journals. tists were mostly agriculturalists, but activities of forest pathologists soon increased. The experiment stations provided a place where scientists with similar interests could meet to discuss potential research needs and how to address those needs.

The second event was really a series of devastating tree diseases that provoked a public reaction for understanding and solutions. This had the effect of increasing public awareness, soon to be followed by public funding, which eventually was responsible for development of controls.

Closely allied with the increased need for educated scientists was the pool of potential candidates created by the establishment of the GI Bill following World War II, through which the government paid college expenses in return for military service. The majority of undergraduate forestry students may feel that studying forest pathology is not very glamorous, but having a large population of potential graduate students assured that at least some would become intrigued by this new science and might even consider a career in forest pathology.

The third major event that had a great influence on our profession was the establishment of the McIntire-Stennis Cooperative Forestry Program. I am afraid that many of our college administrators today have forgotten the rationale behind that program and it might do well for them, and us, to review it. During the first 2 decades following World War II, the bulk of forest pathology research was done by the USDA Forest Service. They wished to farm out some of the shorter termed research projects to colleagues at universities around the country, but did not want to pay what they considered prohibitive indirect costs which reduced the effectiveness of their research dollars. So, in exchange for not having to pay indirect costs, they supported the McIntire-Stennis Cooperative Forestry Program, which provided funding designated specifically for forestry.

The McIntire-Stennis program began modestly in 1964, coincidently the same year that I began my scientific and professional career, and I have been closely supported by it ever since (Fig. 2). Note that the vertical bars represented in Figure 2 are

TABLE 1. List of major textbooks of forest pathology published in North America during the 20th century

\begin{tabular}{ll}
\hline Year of publication & Author \\
\hline 1931 & Hubert (7) \\
$1938,1948,1961$ & Boyce (3) \\
1948,1959 & Pirone (10) \\
1943,1952 & Baxter (1) \\
1970 & Verrall (17) \\
1970 & Smith (14) \\
1971 & Hepting (6) \\
1978 & Tattar (16) \\
1981,1991 & Manion (8) \\
1987 & Sinclair, Lyon, and Johnson (13) \\
1996 & Tainter and Baker (15) \\
\hline
\end{tabular}

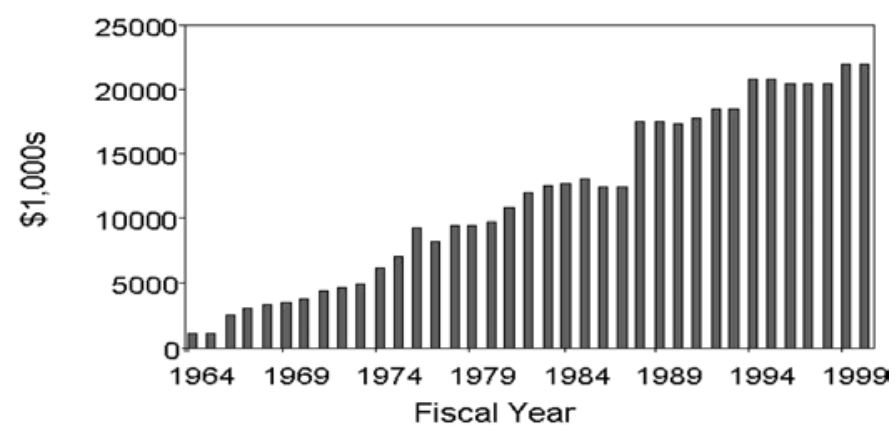

Fig. 2. The funding history of the McIntire-Stennis Cooperative Forestry Program, by year, since the program was started in 1964 (2). The annual funding amounts, which are the appropriated amounts, have not been adjusted for inflation. 
preinflation dollars and that after 1984 the amount in real dollars levels off or increases only slightly. These funds go primarily to states with significant forest cover and are determined by a formula which includes such factors as the proportions of private forest land and federal forest land.

The present. Interestingly, McIntire-Stennis only provides for about $10 \%$ of the university funding for forestry research, with other federal monies providing about a third of the financial support (Fig. 3). The states actually provide almost half of the support, but the changing breakdown of this support will have serious implications.

What proportion of this forestry research is actually related to forest pathology? We can see where the forest pathology-related research funded by various agencies is given for 1975 by using data provided by the Current Research Information System (CRIS) (Table 2). The total number of projects, and the percentage that involve forest pathology, are compared with the actual funding. The same kinds of data are also given for 1995. In comparing the two periods, note that the forest pathology percentages in most of these categories either remained the same or decreased somewhat by 1995 . Most informative are the decreases for state spending in forest pathology, both in numbers of projects and in support dollars. The number of state-supported forest pathology/forestry projects decreased from $43 / 416$ in 1975 , with $7 \%$ of the funding for forest pathology, to $21 / 393$ in 1995 , with only $2 \%$ of the funding for forest pathology. Clearly, the states have become less interested in supporting forest pathology.

The situation is no better within the USDA Forest Service (Table 3). We have known for some time that foresters are not being replaced. Extrapolating beyond a linear regression of the data indicates that if this trend continues there will be no more foresters after 2009 (Fig. 4). The situation is even worse for products specialists. If this trend continues, there will be no more of them in 2004. Things look a little better for forest pathologists, but there will be no more after 2010 . For ecologists, the situation appears to be more optimistic. If the present hiring trend continues, by 2010, when the last pathologist turns off the laboratory lights, there will be at least 96 ecologists.

Shelby Foote, the renowned Civil War historian, remarked that each southern boy at some time in his life recalls with nostalgia back to the way things were on the morning of 3 July 1863 when the South's world was still intact and they were still in control of their destiny. As you may recall, later that day Pickett's charge at the Battle of Gettysburg was the high water mark that changed their future forever. For forest pathologists, especially those who published in Phytopathology, the high water mark was much ear- lier than we might have expected, in December 1974 (Fig. 1), with an article by Welch and Martin (18). Coincidently, the high water mark for forest pathologists who published in Plant Disease (Fig. 1) was also in December 1974, with an article by Phelps (9). For Canadians, the high water mark was earlier, in 1970, but a reduced output was sustained for quite a few years with perhaps somewhat of a recovery in the 1980s (Fig. 1).

These are interesting findings, because if we reexamine the McIntire-Stennis funding history (Fig. 2), the most significant production of refereed publications was at the same time when funding was actually rather modest. What has happened since 1974? Why has our productivity apparently declined? There are several things to consider. Firstly, one can argue that other scientific journals have subsequently carried the bulk of forest pathology publication. Such journals include the Canadian Journal of Forest Research and the European Journal of Forest Pathology. Then too, we must consider the declining number of forest pathologists (Fig. 4; Table 3). Don't fewer pathologists equal fewer articles? Also, what about funding (Table 2)? It appears that total

TABLE 2. Total and percentage of forest pathology/forestry research by agency and program type for 1975 and $1995^{\mathrm{a}}$

\begin{tabular}{llll}
\hline & \multicolumn{1}{c}{1975} & & \multicolumn{1}{c}{1995} \\
\cline { 2 - 2 } Agency & \multicolumn{1}{c}{ Projects//\$1,000s } & & Projects//\$1,000s \\
\hline CSREES & & & \\
Grant & $1 / 7(14 \%)$ & & $8 / 175(5 \%)$ \\
& //no data & & \\
Hatch & $42 / 417(10 \%)$ & & $46 / 238,530(5 \%)$ \\
& $/ /$ no data & & $/ /$ no data \\
McIntire-Stennis & $40 / 458(9 \%)$ & & $49 / 167(8 \%)$ \\
& $/ / 942 / 12,175(8 \%)$ & & $/ / 3,412 / 71,216(5 \%)$ \\
Agricultural & $3 / 25(12 \%)$ & & $6 / 48(12 \%)$ \\
Research Service & $/ /$ no data & & $/ /$ no data \\
Forest Service & $21 / 209(10 \%)$ & & $48 / 431(11 \%)$ \\
& $/ / 4,582 / 58,108(8 \%)$ & & $/ / 7,806 / 135,530(6 \%)$ \\
State & $43 / 416(10 \%)$ & & $21 / 393(5 \%)$ \\
& $/ / 523 / 7,343(7 \%)$ & & $/ / 716 / 45,646(2 \%)$ \\
Total & $150 / 1,332(11 \%)$ & & $186 / 1,957(10 \%)$ \\
& $/ / 6,956 / 84,568(8 \%)$ & & $/ / 7,624 / 293,209(6 \%)$ \\
\hline
\end{tabular}

${ }^{a}$ Numbers in parentheses indicates percentage of total forestry research comprised by forest pathology. Data taken from Current Research Information System (CRIS) ID 012600. The funding numbers are totals of all dollars spent on the respective two areas of research, including various other U.S. Department of Agriculture sources, cooperative state research, education and extension (CSREES) administrative costs, state-appropriated monies (including matching), and other nonfederal costs, and do not equal those annual totals listed in Figure 2.

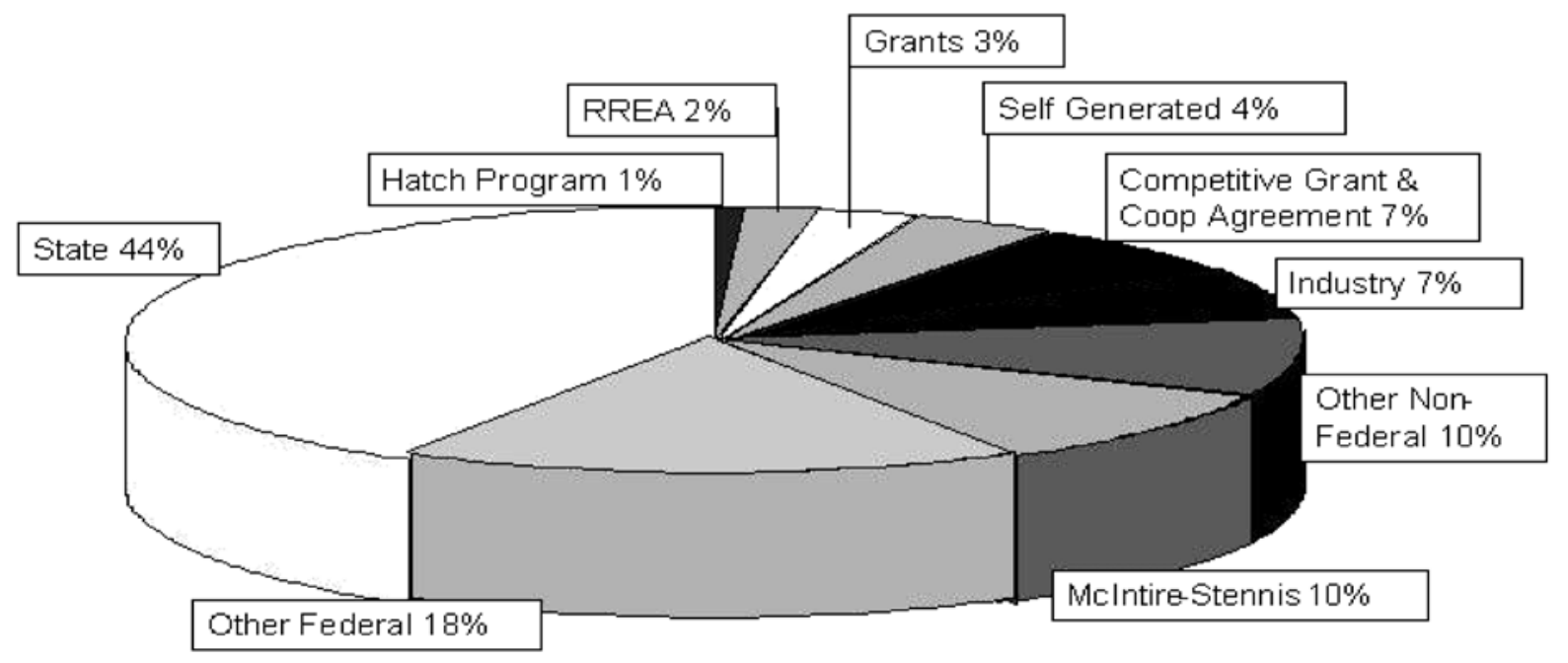

Fig. 3. Funding sources for forestry research in the universities in 1997 (2). 
funding is flat when not adjusted for inflation, but much lower now in real dollars. Don't fewer dollars equal fewer articles?

My own prejudiced experience also suggests that our collective research productivity has declined by some fairly significant extent. In the early years of McIntire-Stennis funding, the monies were expended only on graduate student stipends and their direct support. This led to efficient use of the monies as advisors had direct control of the money. Then, as administrators began to view these monies as an entitlement, they were increasingly used to pay large portions of faculty and staff salaries and to leverage more money out of the states to build larger forestry programs. This meant that advisors had less time for hands-on research and more time was spent on advising students, doing some outreach, and a lot of committee work and other service for the university. Increasing time and energy was also spent on writing research proposals for grants that contain substantial indirect monies to help fund the university.

The future. As I transition into what I think the future holds for our profession, I want to share some questions that the new president of Clemson University posed to the faculty shortly after he took office. After all, many of the frustrations he faced are similar to what we face as we try to grope with a future that is changing in ways faster than we can comprehend or even follow. I selected some of those questions which I think are appropriate and perhaps worthy of a few moments reflection as we think our way through the present period of turmoil.

How has our profession changed over time? Each of you I am sure can draw on your own experience to answer this question. We no longer just report new diseases, although that is still a part of our job, perhaps an even more important one as we move toward a global economy with a greatly increased risk of pathogen movement. We must understand an increasingly complex forested world that now suffers not only from constantly changing biological interactions but increasingly is subject to economic constraints and political nuances. We must not only be good observers, but we must also excel as physiologists, epidemiologists, ecologists, statisticians, mycologists, and outreach public relations specialists.

How does funding affect our mission? McIntire-Stennis has funded a lot of good research, as have cooperative agreements with the Forest Service and other governmental agencies. But, forest pathology has never had the large federally funded initiatives such as the Southern Pine Beetle Program or the Gypsy Moth Program. More than any other issue, funding will be the key to our future success. It has long been my impression that forest entomologists have done better financially than pathologists, and I think that this is partially because of their absolute confidence in what they do. We may need to be more vocal and confident in what we do!

What do we gain or lose by being compartmentalized? In the past, a strong pathologist could function equally well whether in a forestry, botany, or plant pathology department. As the bean counters take over more control within our administrations, I think we may need to consider our placement very carefully. Forest pathology research will be more fairly evaluated by a department chair who is a plant pathologist rather than by a wood products specialist or a geneticist. There is no question though that research projects will be larger and will be cooperative between specialists with varied backgrounds. Our efforts will be recorded on a spreadsheet and be increasingly evaluated by individuals with little or no knowledge of what we really do. At many institutions, scholarship is no longer defined by numbers of refereed research publications but rather by the amount of grant monies obtained.

Where we as professional forest pathologists eventually roost, if we do survive long enough to roost, is going to change as forestry and plant pathology departments come and go. Many forest pathology positions will not survive. Some forestry programs may have trouble justifying their continuance and some plant pathology departments will fold. One can count on one hand the number of forest pathologists left at universities in the southeastern states, and the number of surviving federal forest pathologists is not much greater.

We can make a strong argument that the most heavily forested states need to have a forestry department and certainly one, or more, state-affiliated forest pathologist with a hefty number of USDA Forest Service pathologists thrown in for good measure. In the West, there are five heavily forested states, predominantly of federal or state ownership (Table 4). We are all aware of the disease problems that are widespread on those lands. Who is going to handle these diseases? Ecologists-I don't think so.

In the East, the situation is quite different. The top seven forested eastern states are predominantly in private or industry ownership (Table 5), where forest management is intensive. Here, forest pathologists are needed to handle disease problems resulting from intensive management activities. If you agree with my argument, this means that at least 12 state-funded forest pathology positions, and certainly an equal number of federal forest pathologists, need to be maintained to keep the science alive and prepare for the next renaissance in forest pathology.

Although the situation appears to be pretty glum in the United States, the situation in international forest pathology is actually quite good, especially within the countries governed by the European Economic Community (EEC). Most EEC countries have one or more individuals actively working as forest pathologists and, as a whole, their collective research is of high quality. They appear to have good financial support. Since World War II, several international, and especially European, forestry journals have published an increasing number of significant research discoveries. As U.S. capabilities have declined, international capabilities have increased and set the pace for the first century of the new millennium.

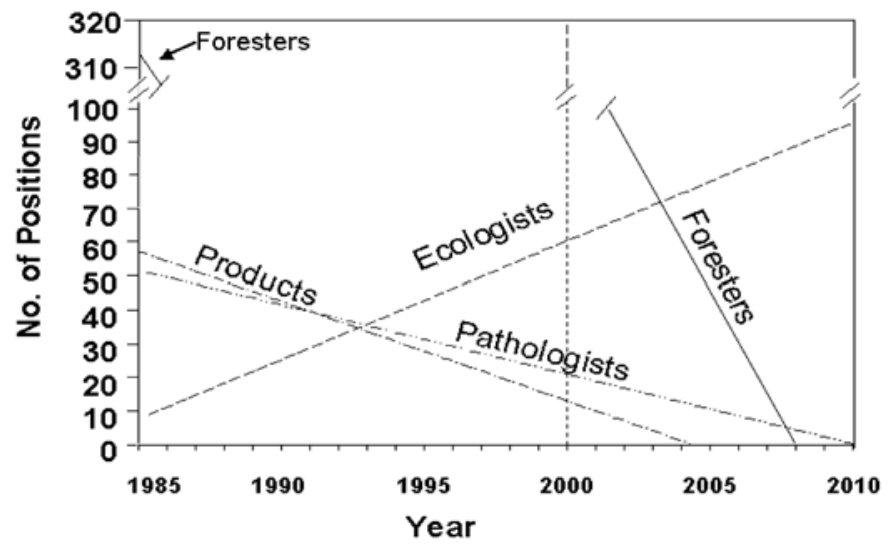

Fig. 4. Extrapolations of data presented in Table 3 to show projected extinction dates for selected U.S. Department of Agriculture Forest Service disciplines.

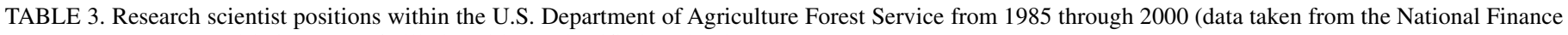
Center (NFC) report entitled "Count of Filled Positions Classified Under the RGBG")

\begin{tabular}{|c|c|c|c|c|c|c|c|c|}
\hline Title & 1985 & 1988 & 1990 & 1995 & 1997 & 1998 & 1999 & 2000 \\
\hline Ecologist & 9 & 18 & 25 & 46 & 52 & 53 & 50 & 55 \\
\hline Forester & 350 & 242 & 230 & 138 & 143 & 138 & 136 & 140 \\
\hline Forest products technician & 63 & 43 & 31 & 25 & 21 & 18 & 13 & 15 \\
\hline Plant pathologist & 50 & 48 & 45 & 35 & 27 & 25 & 22 & 23 \\
\hline
\end{tabular}


TABLE 4. Acreage and ownership of forest lands in the western United States (2) ${ }^{\mathrm{a}}$

\begin{tabular}{lcc}
\hline State & Forest lands (million acres) & Public ownership \\
\hline California & 38.8 & $57 \%$ \\
Oregon & 28.1 & $63 \%$ \\
Montana & 21.9 & $72 \%$ \\
Washington & 21.9 & $60 \%$ \\
Idaho & 21.8 & $77 \%$ \\
\hline
\end{tabular}

a The forests of the West are predominantly in public ownership, mostly federal.

TABLE 5. Acreage of forest lands in the eastern United States (2)a

\begin{tabular}{lc}
\hline State & Forest lands (million acres) \\
\hline Georgia & 22 \\
Alabama & 21 \\
Maine & 18 \\
New York & 17 \\
North Carolina & 16 \\
Mississippi & 16 \\
Pennsylvania & 15
\end{tabular}

a The top seven nonfederal forested states are in the East, where a very small percentage of forests and other lands are in federal ownership.

What do we gain or lose through technology advances? This is easy to answer. We have gained a great deal because of technology. As a former histologist, I have marveled at the utility of the coal-tar dyes that were developed in Germany in the 1830s. Of course, now we have a formidable array of other stains and indicators that can identify specific enzymes, and more, even specific genes and their roles in diseases. The personal computer was a big boon, not only for analyzing large amounts of data, but a great assistance in doing mundane tasks like preparing lectures and even this manuscript. Instrumentation in general is much more sensitive.

The molecular genetic tools at our disposal open a new array of research possibilities in forest pathology. Good students are attracted to new technology because a working knowledge of it gives them an employment advantage. The experience of my last doctoral student is an example of how rapidly this new technology is providing opportunities for understanding forest diseases. She examined the interrelationships of a double-stranded (ds)RNA mycovirus that infects Discula destructiva, the fungus that causes dogwood anthracnose. Different isolates of the fungus yield different kinds of banding patterns of the dsRNA, and within each are different-sized bands. One can study electrophoresis gels of the dsRNA but still not detect many clues as to whether the bands are related and what they represent. But, if you sequence the genetic code of each of these bands, you have a very clear understanding of their interrelationships, their relationships with other fungal dsRNAs, and even the specific products that are encoded (12).

As a response to the value of these tools, new journals are appearing to accommodate the new research. How will forest pathology fare? Not too good so far I fear! If we examine our most closely related scientific journal, Molecular Plant-Microbe Interactions, we see that forest pathology articles have been published at the rate of about two per year over a 10 -year period through 1999. This will certainly increase somewhat as the new technology is more widely adopted. But, is this new technology going to replace the kind of work most of us presently do? For the mental health of those few forest pathologists who survive, I would argue an emphatic NO!

We still have new forest tree diseases being reported at the rate of about 10 or so per year, and there seems to be no indication of a decrease in that rate (Fig. 5). Some of these diseases and their pathogens have simply been overlooked until now, others have only recently become prominent in response to some change in their environment, and others have been introduced into suscepti-

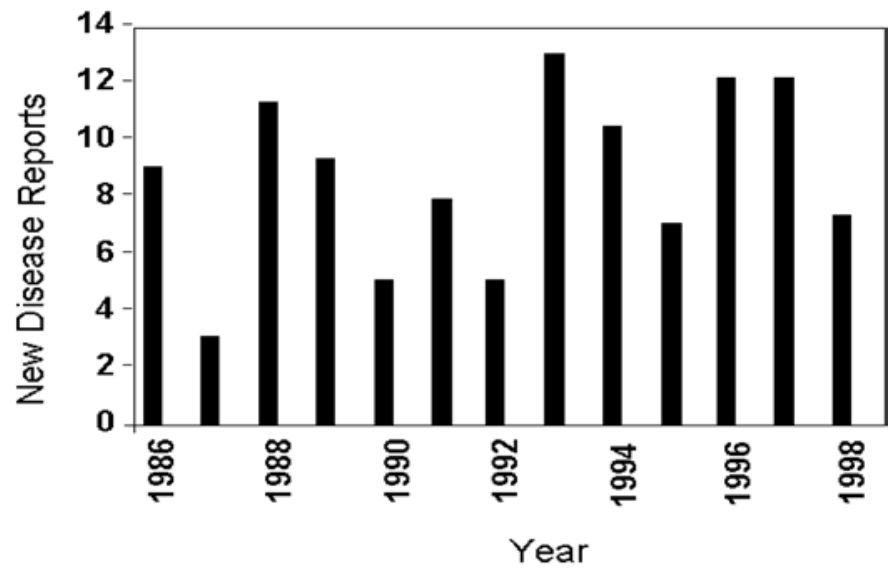

Fig. 5. Reports of new forest tree diseases published in Plant Disease for the years 1986 through 1998.

ble ecosystems. New diseases will always be coming to the forefront, and forest pathologists can count on this as a guarantee of at least some employment in this new era.

But society's views of forest pathology have changed and I think we have become begrudgingly relegated to a state of nonrecognition. This fact was made very clear on 16 June 2000 in a feature article entitled, "In California, Oaks Suddenly 'Bleed' Then Die," published in USA Today. As county authorities requested 3 million dollars to fight the "raging killer," an associate dean of forestry, water officials, ecologists, and horticulturists all had something to say but none offered to inform us of the cause. It was a forest pathologist who, with the aid of his graduate students, fellow coworkers, and some quick funding, showed that good science didn't get discarded in the frenzied politics of impatient public concern.

When David Rizzo released a press report identifying a new species of Phytophthora as the possible cause of the decline, I think forest pathologists everywhere must have been overjoyed! That simple action was a lesson to an increasingly disinterested, yet demanding, public that good science can still provide the answers and that forest pathologists have a valuable function to perform. As the so-called sudden oak death syndrome unfolded, we saw how some of the oldest plant pathology isolation methods were integrated with some of the newest biotechnology to provide quick and accurate answers, and the global positioning system was employed to record field locations (11).

I think that how society views forest pathologists is largely up to us. Unfortunately, we are our own worst enemies. Many forest pathologists are foresters and are typically introverted and, while dedicated to our responsibilities, are not self-aggrandizing. I think it would help our public image if we were a little more forceful in presenting our views on issues relating to forest health. We need to be more like forest entomologists, and if it is not beetles we need to say so!

I have presented to you a very grim picture, but my long-range view is actually very optimistic. For you see, we have the pathogens on our side, and millions of years of evolution tell us in no uncertain terms, that if you have a potential host, the pathogens will come!

\section{LITERATURE CITED}

1. Baxter, D. V. 1952. Pathology in Forest Practice. 2nd ed. John Wiley \& Sons, New York.

2. Bentley, W., Malmsheimer, M. B., and Cairo, J. 2000. The role of education and extension in sustaining America's forest resources: Why you should care. Natl. Assoc. Prof. For. Schools Colleges, U.S. Dep. Agric. Nat. Resour. Environ. Unit, Washington, DC.

3. Boyce, J. S. 1961. Forest Pathology. 3rd ed. McGraw-Hill Book Co., New York. 
4. Crandall, B. S., Gravatt, G. F., and Ryan, M. M. 1945. Root disease of Castanea species and some coniferous and broadleaf nursery stocks, caused by Phytophthora cinnamomi. Phytopathology 35:162-180.

5. Hartig, R. 1874. Important Diseases of Forest Trees. (English translation by W. Merrill, D. H. Lambert, and W. Liese) Julius Springer, Berlin.

6. Hepting, G. H. 1971. Diseases of Forest and Shade Trees of the United States. U.S. Dep. Agric. For. Serv. Agric. Handb. 386.

7. Hubert, E. E. 1931. An Outline of Forest Pathology. John Wiley \& Sons, New York.

8. Manion, P. D. 1991. Tree Disease Concepts. 2nd ed. Prentice Hall, Englewood Cliffs, NJ.

9. Phelps, W. R. 1974. Evaluation of fusiform rust incidence on loblolly and slash pine in the South. Plant Dis. Rep. 58:1137-1141.

10. Pirone, P. P. 1959. Tree Maintenance. 3rd ed. Oxford Press, New York.

11. Rizzo, D. M., Garbelotto, M., Davidson, J. M., and Slaughter, G. W. 2002. Phytophthora ramorum as the cause of extensive mortality of
Quercus spp. and Lithocarpus densiflorus in California. Plant Dis. 86:205-214.

12. Rui, R., Rao, S., Scott, S. W., Carner, G. R., and Tainter, F. H. 2002. Complete sequence of the genomes of two dsRNA viruses from Discula destructiva. Virus Res. 90:217-224.

13. Sinclair, W. A., Lyon, H. H., and Johnson, W. T. 1987. Diseases of Trees and Shrubs. Cornell University Press, Ithaca, NY.

14. Smith, W. H. 1970. Tree Pathology: A Short Introduction. Academic Press, New York.

15. Tainter, F. H., and Baker, F. A. 1996. Principles of Forest Pathology. John Wiley \& Sons, New York.

16. Tattar, T. A. 1978. Diseases of Shade Trees. Academic Press, New York.

17. Verrall, A. F. 1970. Diseases of Forest Trees and Forest Products. Stephen F. Austin State Univ. For. Bull. 21.

18. Welch, B. L., and Martin, N. E. 1974. Invasion mechanisms of Cronartium ribicola in Pinus monticola bark. Phytopathology 64:1541-1546. 